\title{
Morphology, Structure and Mechanical Properties of Polypropylene Modified with Organophilic Montmorillonite
}

\author{
Ana R. Morales, Lucilene B. de Paiva, Daniela Zattarelli \\ Departamento de Tecnologia de Polímeros, UNICAMP \\ Thiago R. Guimarães \\ Departamento de Metalurgia e Engenharia de Materiais, EPUSP
}

\begin{abstract}
The aim of this work is to study the properties of systems based on polypropylene (PP) and commercial organophilic montmorillonite, prepared by melt intercalation. Because of the non polar character of PP, the polypropylene-graft-maleic anhydride (PP-g-MA) was used as compatibilizer. Materials containing 2.5, 5, 7.5 and 10\% of clay and PP, and two extra compositions containing only PP and 15 and $30 \%$ of PP-g-MA were processed using a twin-screw extruder. The level of clay dispersion was characterized by $\mathrm{X}$ ray diffraction, showing exfoliated/intercalated structures for different concentrations of clay. The crystallization behavior was studied by differential scanning calorimetry (DSC) and polarizing optical microscopy (POM) with hot stage. Tensile properties were also studied and presented a moderate improvement with increase in clay concentration.
\end{abstract}

Keywords: Montmorilonite, organoclay, crystallization, morphology, mechanical properties.

\section{Introduction}

Nanotechnology applied to polymer has received a significant attention in research and development. According to Paul and Robenson $^{[1]}$, nanotechnology is not new to polymer science as prior studies were done in the past but were not specifically referred to as nanotechnology until recently.

Systems based on intercalation of polymer chains into organically modified clay are one of the most studied ${ }^{[2-9]}$. The formation of nanocomposite depends on the type of surfactant intercalated on clay layers, polarity of surfactant, polymer matrix nature (olefinic/nonolefinic) and processing conditions ${ }^{[10]}$. Nanocomposites generally present improvement in mechanical and thermal properties, flame retardancy, and decreasing permeability of gases and vapors at lower filler concentration, compared to neat polymers and conventional composites ${ }^{[11,12]}$. The unique properties of nanocomposites can be attributed to their nano-sized features and the extremely high surface area of the dispersed clay ${ }^{[12]}$.

Although progresses have been made in polymer nanocomposites many questions have yet to be answered. One of these questions is related to changes in polymer crystallinity induced by the clay and its consequences on overall properties of the composite ${ }^{[12]}$

Polypropylene is a versatile polymer being widely used in packaging, technical automotive parts, and compounds. The possibility to improve its mechanical and barrier properties can open new opportunities of application. The study on nanocomposites, where dispersed and organophilic clay is used as reinforcement is becoming increasingly popular on academic and industrial field. Besides the modification on mechanical properties due to the reinforcement by the clay nanolayers, there is an important aspect to be studied: the influence of the nanolayers on the crystallinity of the PP that can, by itself play a role on the final properties of the nanocomposite. In semicrystalline polymers, the nucleation stage is a critical step on crystallization process and parameters like crystallization rate, degree of crystallinity, morphology and spherulites size directly affect the final physical properties ${ }^{[13-15]}$. The crystallization of iPP (isotactic polypropylene) is controlled by the nucleation stage, and the addition of nucleating agents to shorten the induction time of crystallization and accelerate the formation of crystalline nuclei is a technique commonly used in the polymer industry to decrease injection-molding cycle times ${ }^{[13]}$. Furthermore, the agents also generate smaller spherulites and increase crystallinity, thus improving the optical and mechanical properties ${ }^{[13,15]}$. Lv et al. ${ }^{[16]}$ prepared polypropylene composites with organically modified zeolite. They found that the addition of small amount of modified zeolites lead to increase in crystallization temperature, initial crystallization temperature and crystallinity of PP which was responsible for higher tensile and flexural strength. The nonisothermal crystallization behavior of nylon6(PA6)/attapulgite (AT) composites was studied by Shi et al. ${ }^{[17]}$ using differential scanning calorimetry, which indicated that AT nano-particles acted as nucleating agents during the crystallization of PA6/AT blends. Several authors present results based on PP crystallization process ${ }^{[13,18-22]}$. The nucleating effect of nanoparticules of montmorilonite on crystallization process of systems based on PP + PP-g-MA (maleic anhydride grafted polypropylene) has been studied by Maiti et al. ${ }^{[23]}$, and they related the decrease of spherulite size with increasing clay content which indicates that clay particles act as nucleating agents. They observed also that PP d-spacing increases and both the lamellar thickness and long period of the nanocomposite are higher than those of PP + PP-gMA. It was explained by the polymer chain tethering to silicate layers. In general, there are two mutually opposite effects of silicate layers on the crystallization behavior: nucleating ability and growth retardation, both of which are related to the content and dispersion state of clay ${ }^{[24]}$.

This work describes the preparation of nanocomposite based on polypropylene-clay using an organically modified montmorillonite and polypropylene-graft-maleic anhydride (PPg-MA) by melt intercalation. Structure of nanocomposites was characterized by $\mathrm{X}$ ray diffraction. Crystallization process was analyzed by differential scanning calorimetry and polarized light optical microscopy. Tensile tests were done to evaluate mechanical properties.

Autor para correspondência: Ana R. Morales, Departamento de Tecnologia de Polímeros, Universidade Estadual de Campinas - UNICAMP, 


\section{Experimental}

\section{Materials, preparation and characterization}

The samples were prepared using organophilic montmorillonite Cloisite 20A supplied by Southern Clay modified with 2M2HT: dimethyl, dehydrogenated tallow, quaternary ammonium, density of $1.77 \mathrm{~g} / \mathrm{cc}$, less than $2 \%$ of moisture and $\mathrm{d}_{001}=24,2 \mathrm{~A}^{\mathrm{o}}$; nucleated homopolymer polypropylene (PP) XM6150K from Quattor, MFI of $35 \mathrm{~g} / 10 \mathrm{~min}$, density of $0.905 \mathrm{~g} / \mathrm{cc}$ and polypropylene-graftmaleic anhydride (PP-g-MA) Orevac CA100 from Atofina, MFI of $10 \mathrm{~g} / 10 \mathrm{~min}$, density of $0.909 \mathrm{~g} / \mathrm{cc}$ and MA content of $1 \%$.

First a masterbatch containing $25 \%$ of Cloisite $20 \mathrm{~A}$ and $75 \%$ of PP-g-MA was processed by using a twin-screw extruder ZSK 25 Mega Compounder Werner Pfleiderer, $\mathrm{L} / \mathrm{D}=36$, through five temperature zones, $230,140,140,150,160{ }^{\circ} \mathrm{C}$ and $300 \mathrm{rpm}$. The

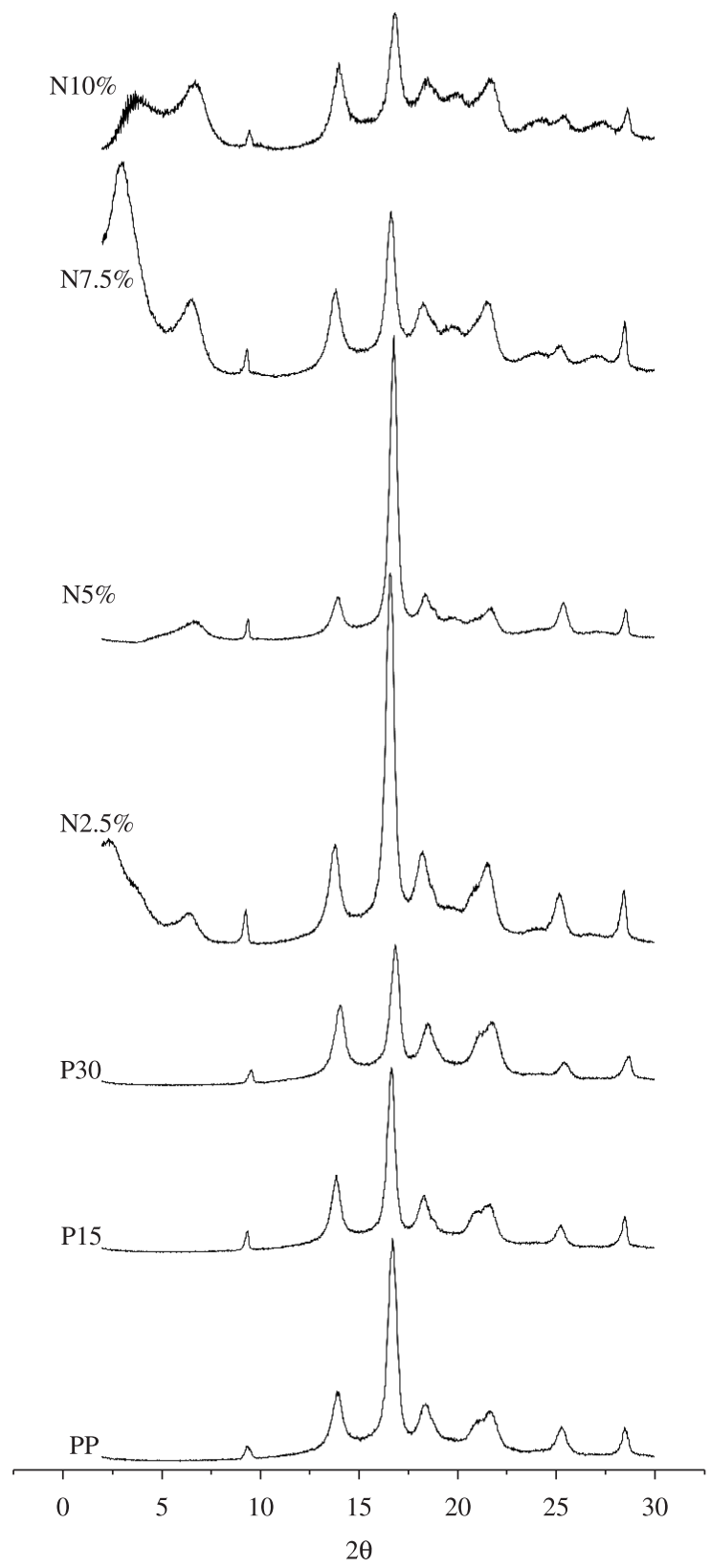

Figure 1. X ray diffraction patterns of PP and modified PP systems. temperature of $230{ }^{\circ} \mathrm{C}$ in the first temperature zone was to promote a faster melt of the polymer and to facilitate the dispersion of the clay. The temperature was kept at $140-160{ }^{\circ} \mathrm{C}$ on the following temperature zones to avoid thermal degradation of polymer and the organic salt intercalated in the clay.

Four different compositions were prepared by dilution of the masterbatch to $2.5,5,7.5$ and $10 \%$ of the organoclay on PP in the same conditions and equipment of the masterbatch. They correspond to $\mathrm{N} 2.5, \mathrm{~N} 5, \mathrm{~N} 7.5$ and $\mathrm{N} 10 \%$, respectively. In order to verify the influence of PP-g-MA and clay in the PP matrix two compositions containing 15 and $30 \%$ of PP-g-MA without clay were also processed at the same conditions, which are identified as $\mathrm{P} 15$ and $\mathrm{P} 30$.

The crystal characteristic and the interplanar distance for plane 001 of the montmorillonite were determinate by $\mathrm{X}$ ray diffraction with difractometer Philips, Model X'Pert operating at $40 \mathrm{KV}$, current of $20 \mathrm{~mA}, \mathrm{Cu}$ radiation, $\lambda=1.5406 \AA$, between $2 \theta=2.0-30.0^{\circ}$.

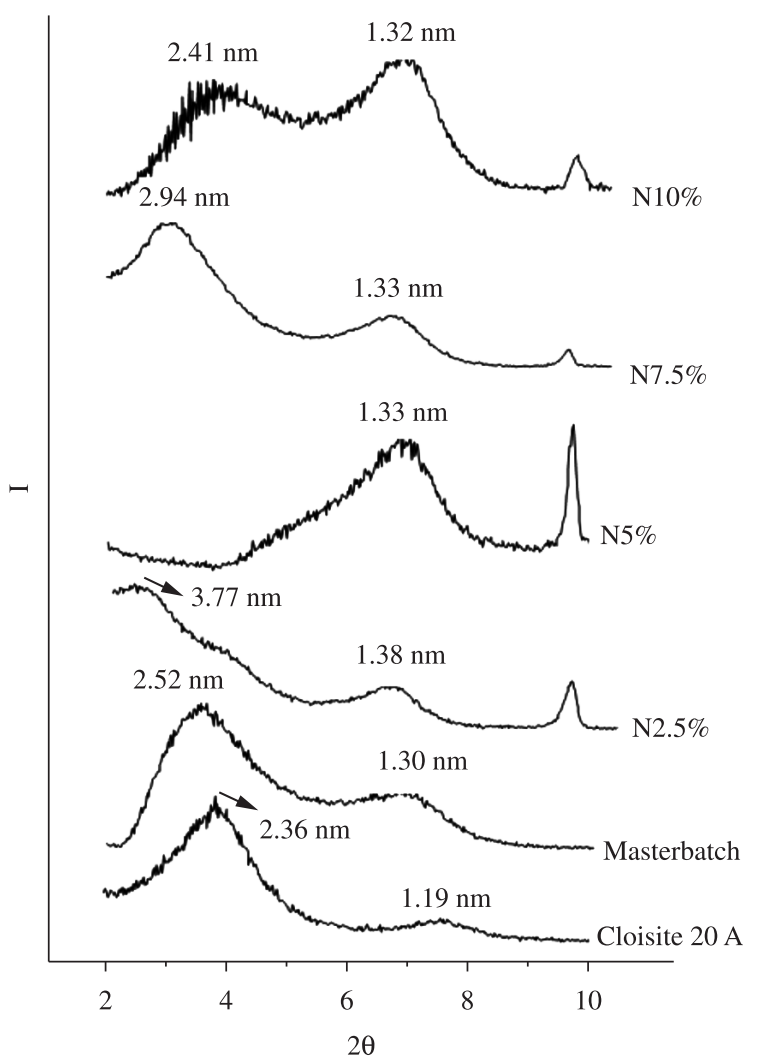

Figure 2. $\mathrm{X}$ ray diffraction patterns of clay, masterbatch and modified PP systems.

Table 1. Values for onset temperature (To), crystallization peak temperature $(T c)$ and crystallization enthalpy change $(\Delta H c)$ for PP and modified PP systems at cooling rate of $10^{\circ} \mathrm{C} / \mathrm{min}$.

\begin{tabular}{cccc}
\hline Sample & $\boldsymbol{T o}\left({ }^{\circ} \mathbf{C}\right)$ & $\boldsymbol{T} \boldsymbol{c}\left({ }^{\mathbf{C}} \mathbf{C}\right)$ & $\Delta \boldsymbol{H} \boldsymbol{c}\left(\mathbf{J . g}^{-1}\right)$ \\
\hline PP & 124 & 120 & 127 \\
P15 & 123 & 120 & 117 \\
P30 & 123 & 120 & 110 \\
N2.5\% & 124 & 120 & 113 \\
N5\% & 123 & 119 & 113 \\
N7.5\% & 122 & 116 & 112 \\
N10\% & 122 & 116 & 113 \\
\hline
\end{tabular}


The Differential Scanning Calorimeter (DSC), Mettler Toledo $822 \mathrm{E} / 500$, was used to evaluate the crystallization process. Isothermal crystallization conditions at 126 and $132{ }^{\circ} \mathrm{C}$ were used. Non-isothermal conditions were carried out at a cooling rate of $10{ }^{\circ} \mathrm{C} / \mathrm{min}$. All scanning was done using a purge of $\mathrm{N}_{2} 50 \mathrm{~mL} / \mathrm{min}$. The crystallization process was observed by polarized optical microscopy (POM) on equipment Leica DMRXP, with hot stage Linkam, THMS600 monitored by a temperature controller Linkam, TMS92 and a video camera KAPPA. The samples were first heated at $210{ }^{\circ} \mathrm{C}$ for 5 minutes and then cooled at $10^{\circ} \mathrm{C} / \mathrm{min}$. Mechanical properties were evaluated by tensile tests according ASTM D638 at $50 \mathrm{~mm} / \mathrm{min}$, in Emic equipment, Model DL2000.

\section{Results and Discussion}

\section{$X$ ray diffraction}

Figure 1 shows the $\mathrm{X}$ ray diffraction patterns of PP, PP modified with PP-g-MA and PP modified with organoclay. Considering the $\mathrm{PP}$ peaks on the region of $2 \Theta$ between 13 to $30^{\circ}$, there is no evidence of crystal phase changes for any of the analyzed samples. Figure 2 shows the $\mathrm{X}$ ray diffraction patterns of the clay, masterbatch and modified PP, for $2 \Theta$ from 2 to $10^{\circ}$ and interplanar distances $d_{001}$ of the clay can be determined. Considering the diffraction peaks related to the (001) reflexions, Cloisite 20A showed a basal spacing $\mathrm{d}_{001}=2.36 \mathrm{~nm}$. The masterbatch showed $\mathrm{d}_{001}=2.52 \mathrm{~nm}$ that suggests intercalation of the clay. The $\mathrm{N} 2.5 \%$ showed $\mathrm{d}_{001}=3.77 \mathrm{~nm}$, that corresponds to an increase of $1.41 \mathrm{~nm}$ compared to the clay, indicating that intercalated structure was maintained. N7.5 and $\mathrm{N} 10 \%$ showed peaks with $\mathrm{d}_{001}=2.94 \mathrm{~nm}$ and $\mathrm{d} 001=2.41 \mathrm{~nm}$, respectively, indicating also intercalated structures. A diffraction peak appeared for all samples in the region corresponding to an interplanar distance from $1.19 \mathrm{~nm}$ to $1.32 \mathrm{~nm}$, which can be attributed to the (002) reflexion. For the sample N5\% the (001) reflexion was not observed, however the (002) reflexion is present. This result suggests that the diffraction peak associated to plane (001) is in a region lower than $2^{\circ}$, which was not detected by the technique. It is reasonable to consider that intercalated structure was formed for this sample also. The results of XRD, related to the clay $\mathrm{d}$-spacing were discussed in more details in previous work ${ }^{[25]}$.

\section{DSC and POM}

To study the effect of the clay on the crystallization process of PP, the non-isothermal and isothermal crystallization DSC scans were carried out. Table 1 shows values for onset temperature (To), crystallization temperature $(T c)$ and crystallization enthalpy $(\Delta H c)$ for PP, PP + PP-g-MA and PP modified with the organoclay for a cooling rate of $10{ }^{\circ} \mathrm{C} / \mathrm{min}$. First, it can be seen that the PPg-MA does not cause significant change on the PP crystallization temperatures, having no effect neither on nucleation or crystallization rate. However, the values of $\Delta \mathrm{H}$ were reduced, indicating a reduction on degree of crystallinity. Divergent results were found by Vladimirov et al. ${ }^{[26]}$, where the PP-g-MA acted as a nucleating agent. They used a PP-g-MA with a MA content of $0,6 \%$ and MFI of $115 \mathrm{~g} / 10 \mathrm{~min}$ at concentrations that varied from $1 \%$ to $5 \%$ and noticed that the nucleation effect are more evident to high amount

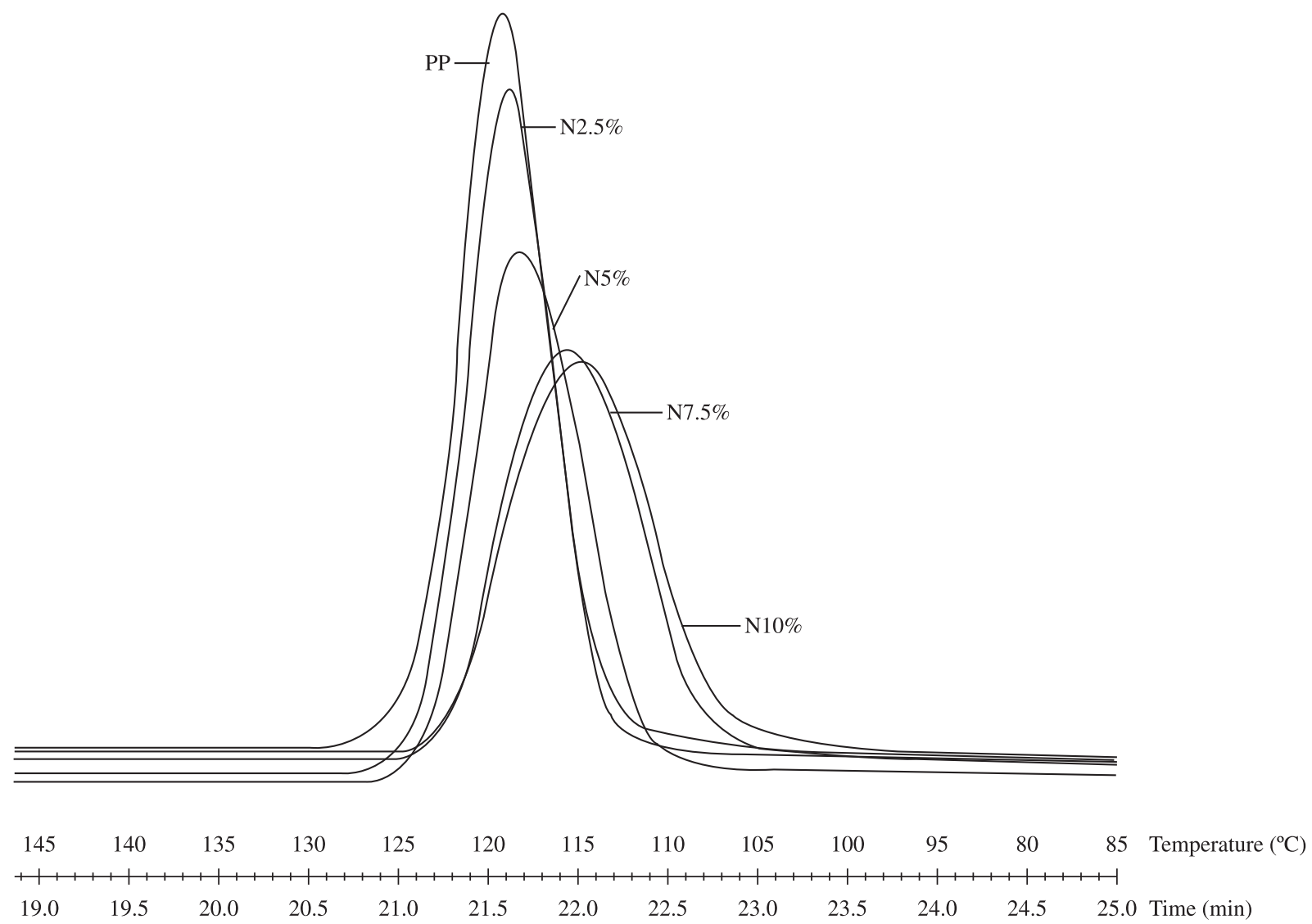

Figure 3. DSC curves for PP and N2.5, N5, N7.5 e N10\%. 


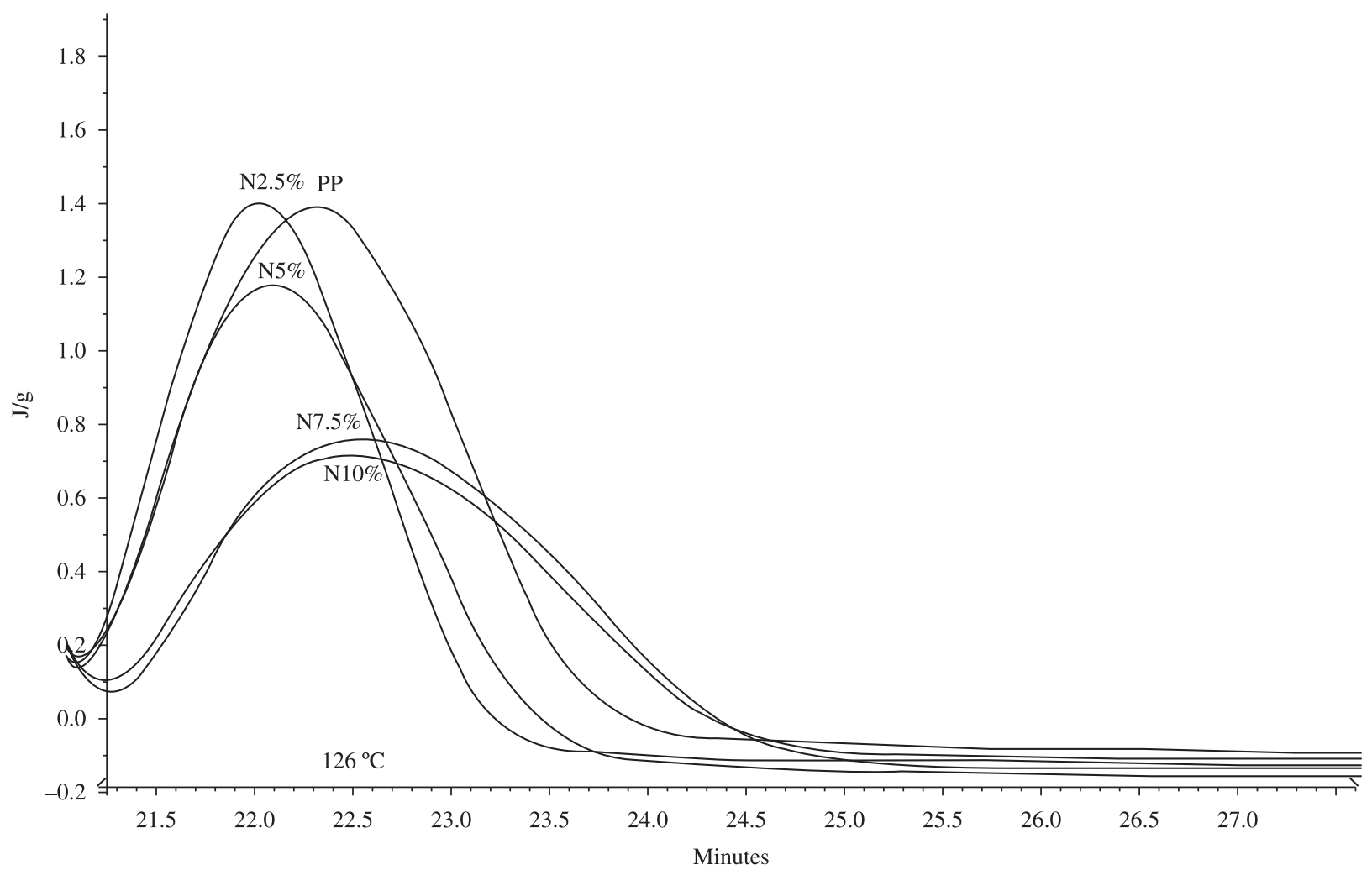

(a)

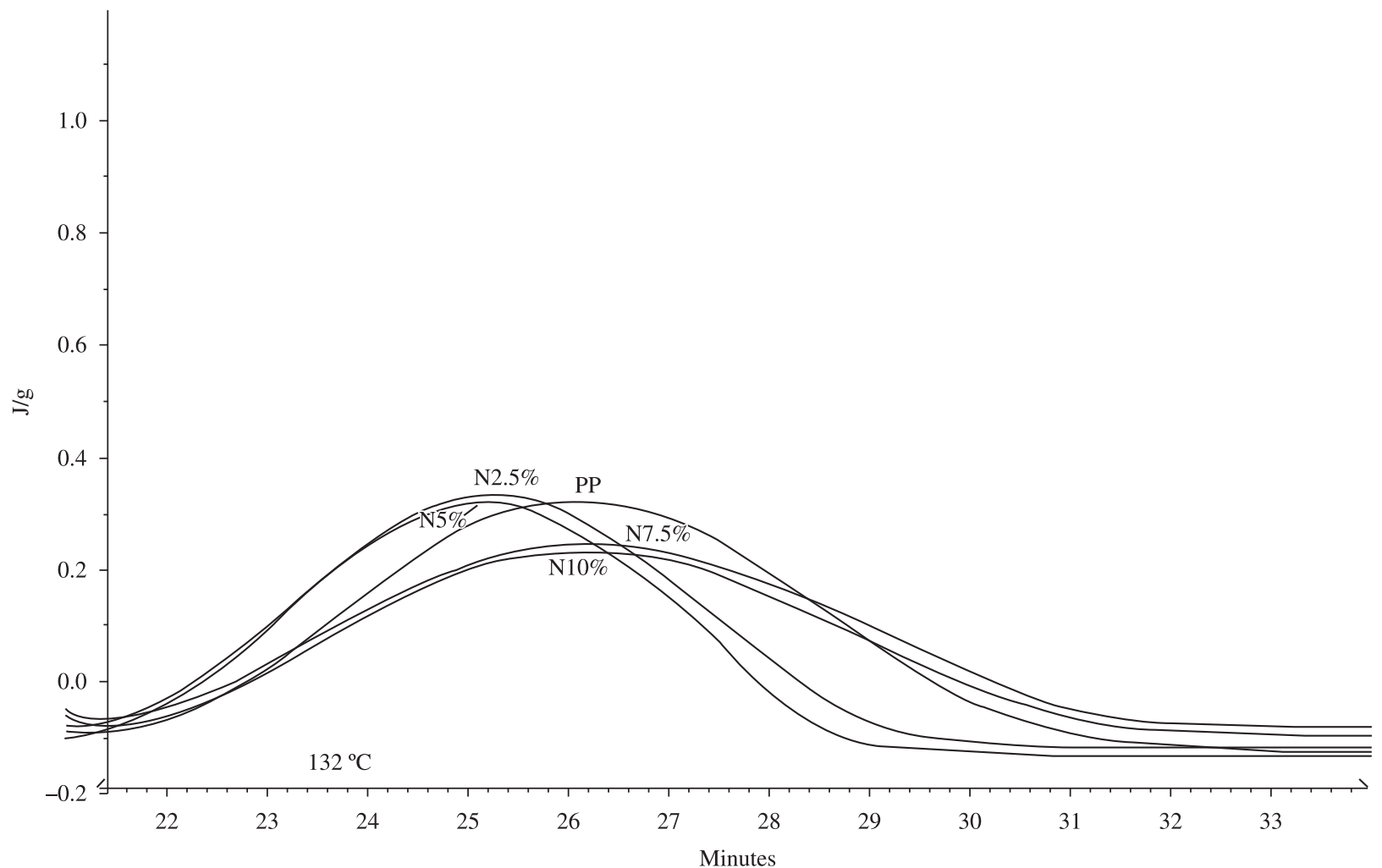

(b)

Figure 4. Isothermal crystallization curves at a) $126^{\circ} \mathrm{C}$ and b) $132{ }^{\circ} \mathrm{C}$. 


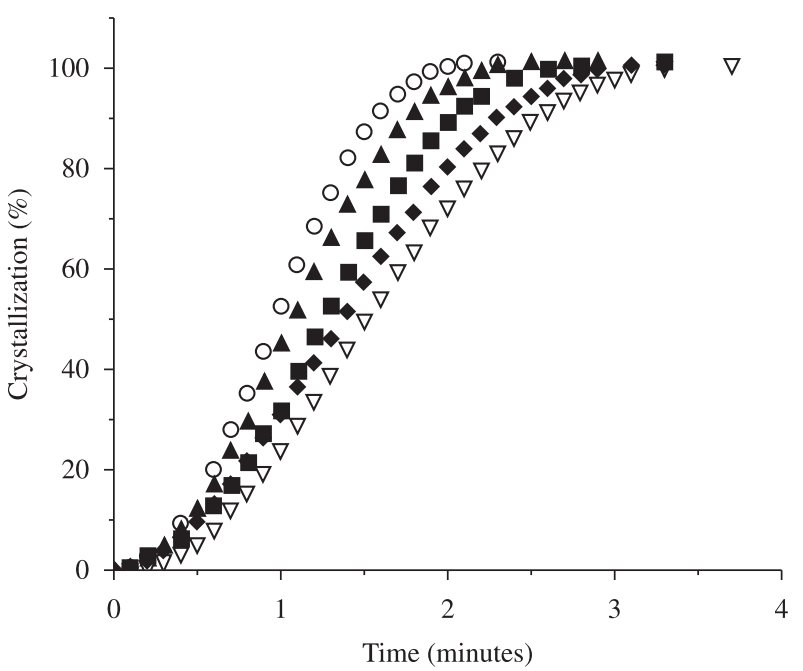

(a)

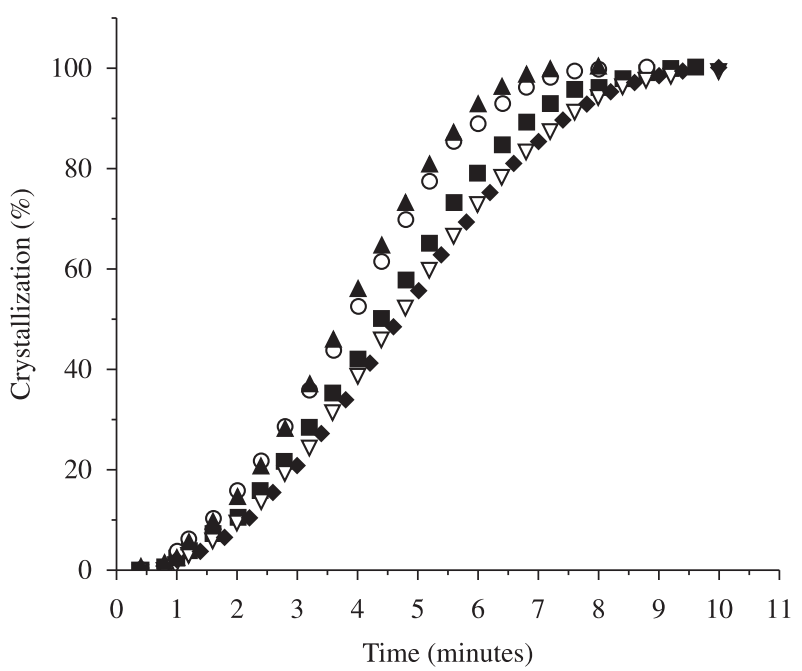

(b)

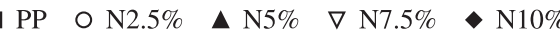

Figure 5. Conversion curves for isothermal crystallization at a) $126{ }^{\circ} \mathrm{C}$ and b) $132{ }^{\circ} \mathrm{C}$.

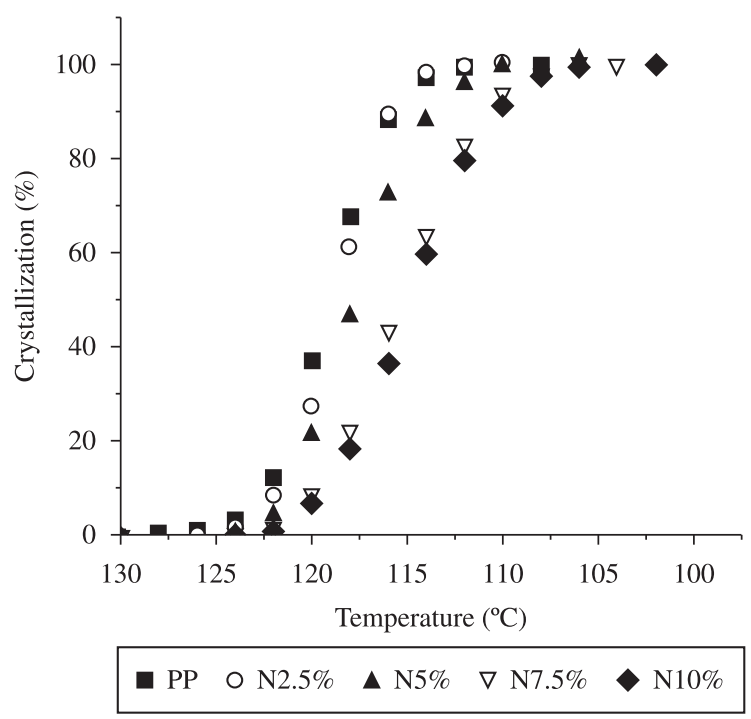

Figure 6. Conversion curves for non-isothermal crystallization at $10^{\circ} \mathrm{C} / \mathrm{min}$.

of the PP-g-MA. Cho et al. ${ }^{[27]}$ analyzed the behavior of PP/PP-g-MA (50/50) blends, where the PP-g-MA has a MFI of $2000 \mathrm{~g} / 10 \mathrm{~min}$. The PP-g-MA caused a co-crystallization on the system and interfered on the crystallization process. Probably due to the higher molecular weight of the PP-g-MA, our systems are less influenced by the compatibilizer. Some aspects like molecular weight or MA grafting level on PP-g-MA are related to cause different behavior ${ }^{[28]}$. In our work there is no detectable influence of PP-g-MA on PP crystal morphology analyzed by DSC curves or DRX patterns.

Considering the presence of clay particles, no evidence of nucleating effect is observed on DSC curves. The crystallization onset occurs at the same temperature for all samples. However crystallization peak temperature slightly decreased and the crystallization peak became broader with the clay content, as shown in Figure 3. As the studied PP is a nucleated grade, it is not possible to say that the clay particles act as nucleating agent, although important reduction on spherulite size is observed on PP modified with organoclay as shown by POM results presented following. It can be suggested that more number of nuclei is formed with the presence of the clay and the effectiveness of the nanoparticles as nucleating agent is present. The peak broadening can be explained by the restriction of polymer chains movement caused by clay layers. Enthalpy data are normalized with respect to the actual mass of polymeric matrix in the samples. $\Delta \mathrm{H}$ values for $\mathrm{PP}$ modified with organoclay are very close to those of PP + PP-g-AM and suggest no reduction on $\mathrm{PP}$ overall crystallinity.

Figures $4 \mathrm{a}$ and $\mathrm{b}$ show isothermal crystallization curves for 126 and $132{ }^{\circ} \mathrm{C}$ respectively. Considering that the PP is already nucleated, for low level of clay $(2.5$ and $5 \%)$ there is there is an increase in the rate of crystallization in the initial stage of the crystallization process. For higher level of clay (7.5 and 10\%) crystallization rate is reduced. It can be seen also on the conversion curves shown on Figure 5. It is important to notice that the same behavior is observed at both crystallization temperatures. It is known that the clay can cause other side-effects besides influencing the polymer nucleation process ${ }^{[4,22,24,26]}$. Movement restraint can be an explanation for changes on crystallization process, but not the only one. Clay layers have high surface area due to their high aspect ratio and can cause, for example, fostering of $\gamma$-phase crystals and lamella thickening ${ }^{[23]}$.

However, no change in PP's crystal forms were observed in the present work, as also reported in some other studies ${ }^{[5]}$. Due to the complexity of this kind of system, aspects related to types of clay, its structure and organic surfactant must be considered ${ }^{[22]}$.

In dynamic crystallization condition where time for chain arrangement is distinct from the isothermal condition, the same behavior was also present. The non-isothermal analysis, on Figure 6, shows again that the conversion rate decreased with clay content.

The isothermal crystallization data were analyzed by Avrami expression as described:

$$
\mathrm{X}(\mathrm{t})=1-\exp \left(-\mathrm{k} \cdot \mathrm{t}^{\mathrm{n}}\right)
$$

where $X(t)$ is the crystalline fraction in the crystallized material at time $\mathrm{t}$, and $\mathrm{k}$ and $\mathrm{n}$ are constants typical of a given crystalline morphology and type of nucleation: $\mathrm{k}$ is the temperature-dependent crystallization rate constant, and $\mathrm{n}$ is the Avrami index ${ }^{[29]}$. Table 2 
shows a value of $\mathrm{n}$ close to 2 for all samples, which suggest a heterogeneous nucleation for a bidimensional growth of the crystals. However, in contrast, the POM microscopy showed spherulitic

Table 2. Avrami index $\mathrm{n}$ and constant $\mathrm{k}$.

\begin{tabular}{|c|c|c|}
\hline & $\mathbf{n}$ & $\mathbf{k}$ \\
\hline \multicolumn{3}{|l|}{ PP } \\
\hline $126^{\circ} \mathrm{C}$ & 1.97 & $1.32 \times 10^{-4}$ \\
\hline $132{ }^{\circ} \mathrm{C}$ & 2.41 & $1.04 \times 10^{-6}$ \\
\hline \multicolumn{3}{|l|}{$\mathrm{N} 2.5$} \\
\hline $126^{\circ} \mathrm{C}$ & 2.04 & $1.69 \times 10^{-4}$ \\
\hline $132{ }^{\circ} \mathrm{C}$ & 2.27 & $3.01 \times 10^{-6}$ \\
\hline \multicolumn{3}{|l|}{ N5.0 } \\
\hline $126^{\circ} \mathrm{C}$ & 2.11 & $1.03 \times 10^{-4}$ \\
\hline $132{ }^{\circ} \mathrm{C}$ & 2.46 & $1.14 \times 10^{-6}$ \\
\hline \multicolumn{3}{|l|}{ N7.5 } \\
\hline $126^{\circ} \mathrm{C}$ & 2.15 & $4.30 \times 10^{-5}$ \\
\hline $132^{\circ} \mathrm{C}$ & 2.49 & $6.15 \times 10^{-7}$ \\
\hline \multicolumn{3}{|l|}{ N10 } \\
\hline $126^{\circ} \mathrm{C}$ & 1.85 & $1.50 \times 10^{-4}$ \\
\hline $132{ }^{\circ} \mathrm{C}$ & 2.49 & $5.49 \times 10^{-7}$ \\
\hline
\end{tabular}

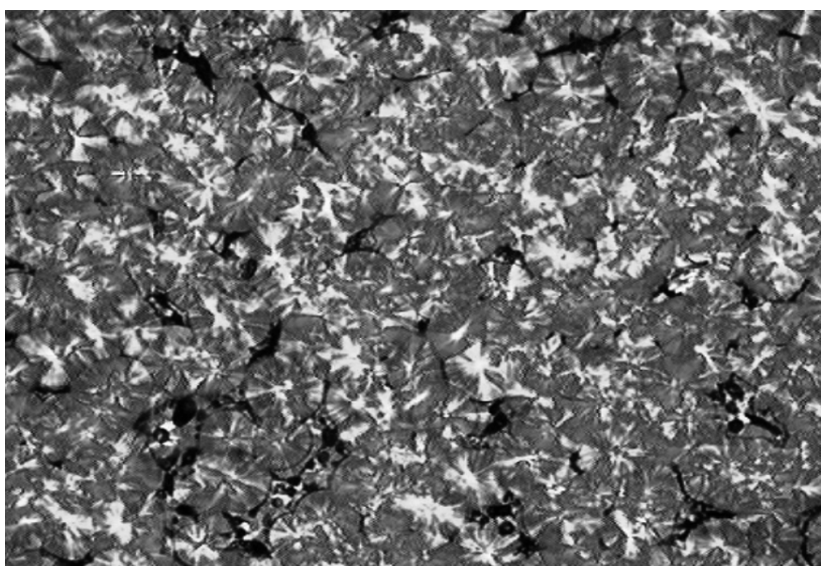

(a)

Figure 7. POM micrographs for a) PP and b) PP15 (200X).

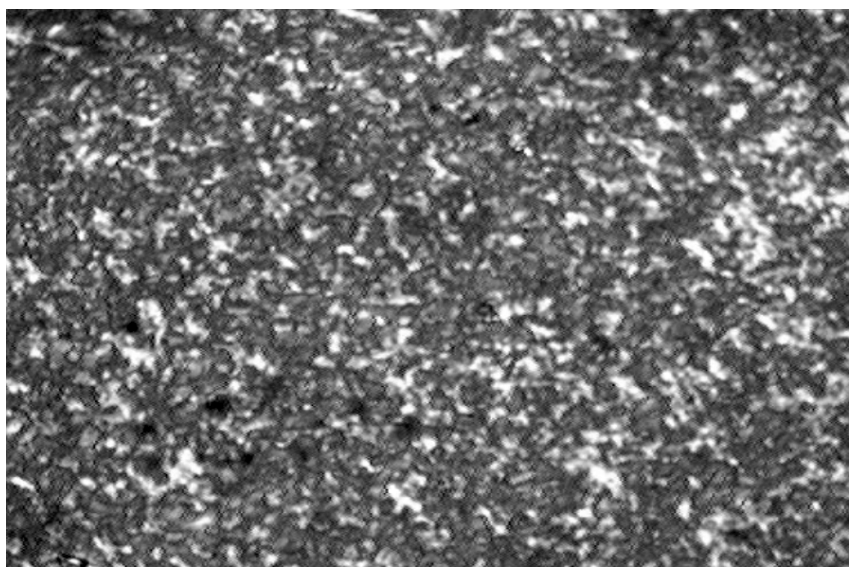

(a) morphology. The same behavior showing discrepancy between the $\mathrm{n}$ value and the mechanism of crystal grow was reported by Avella et al. ${ }^{[29]}$ and was assumed to be due to a deviation of the Avrami expression which contains a number of simplifications. The constant $\mathrm{k}$ decreases as the crystallization increases. For PP and PP modified with small amount of clay, 2.5 and $5 \%$, k values are very similar. Differences can be observed for 7.5 and $10 \%$.

Besides the DSC analysis, the POM micrographs showed the effect of the compatibilizer and the clay on the PP spherultite size. It can be noticed in Figure 7 that there are no differences on spherulite size for pure PP and the PP with the compatibilizer. However for the composites, shown in Figure 8, it can be observed that clay layers promote a reduction in the spherulite size and also a distortion in the spherulite shape. This observation is in good agreement with other studies and this behavior occurs due to a nucleation effect of dispersed clay layers that can interfere on chains folding during crystallization process and restrict the spherulites free growth and, thereby, causing some distortion ${ }^{[14]}$. This is an indication that in the studied system, restraint in the movement of the chains is occurring during crystal growth and explains the observed DSC results.

\section{Mechanical properties}

Tensile results are reported in Table 3. The results showed that PP-g-MA does not affect the tensile modulus of PP and there is no significant increase for composites when clay content goes from

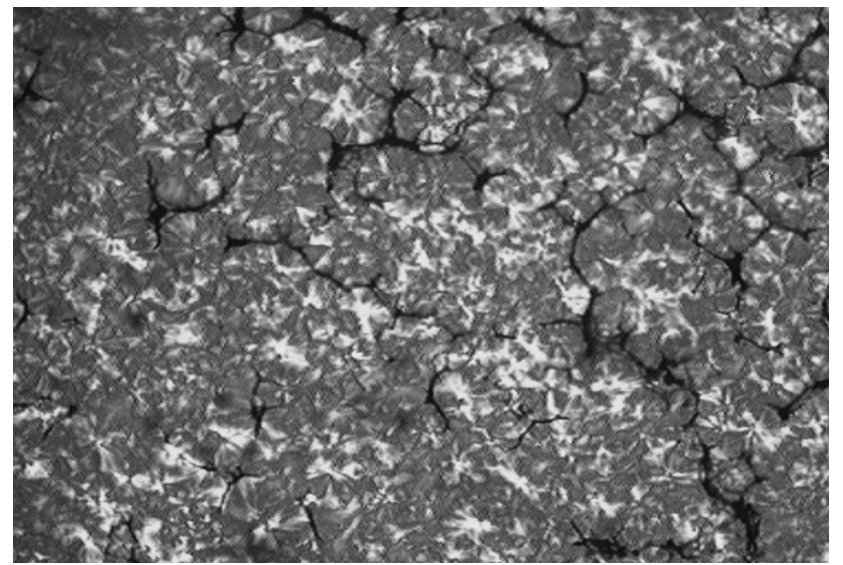

(b)

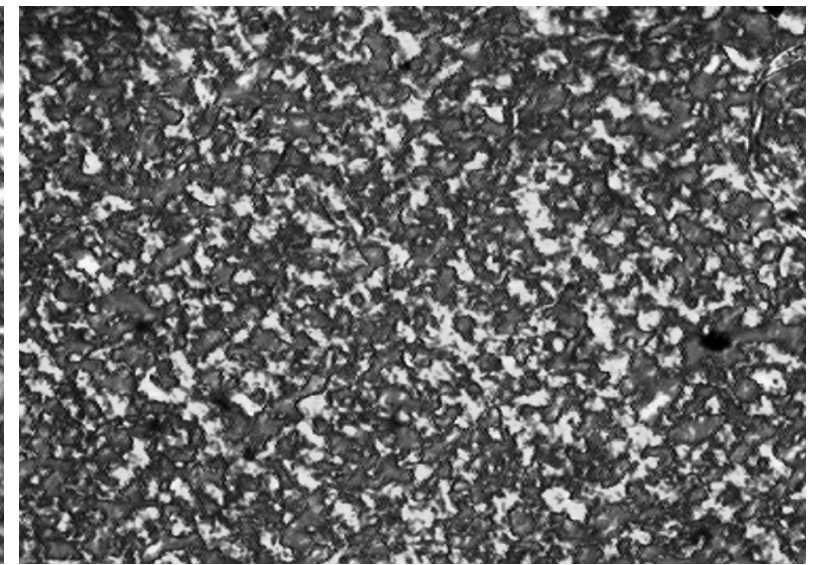

(b)

Figure 8. POM micrographs for a) N2.5\% and b) N5\% (200X). 
Table 3. Tensile Properties of PP and modified PP systems.

\begin{tabular}{cccccc}
\hline Composition & $\begin{array}{c}\text { Tensile } \\
\text { modulus } \\
(\mathbf{M P a})\end{array}$ & $\begin{array}{c}\text { Maximum } \\
\text { stress } \\
(\mathbf{M P a})\end{array}$ & $\begin{array}{c}\text { Yield } \\
\text { stress } \\
(\mathbf{M P a})\end{array}$ & $\begin{array}{c}\text { Strain } \\
\text { at max. } \\
\text { stress } \\
(\boldsymbol{\%})\end{array}$ & $\begin{array}{c}\text { Strain } \\
\text { at break } \\
(\%)\end{array}$ \\
\hline PP & $336 \pm 4$ & $35 \pm 1$ & $17 \pm 4$ & $23 \pm 1$ & $345 \pm 43$ \\
P15 & $336 \pm 6$ & $34 \pm 1$ & $12 \pm 6$ & $23 \pm 1$ & $712 \pm 35$ \\
P30 & $333 \pm 7$ & $33 \pm 1$ & $22 \pm 4$ & $21 \pm 1$ & $41 \pm 9$ \\
N2.5\% & $352 \pm 4$ & $35 \pm 1$ & $23 \pm 8$ & $22 \pm 1$ & $38 \pm 4$ \\
N5\% & $359 \pm 4$ & $34 \pm 1$ & $31 \pm 1$ & $21 \pm 1$ & $30 \pm 2$ \\
N7.5\% & $364 \pm 7$ & $33 \pm 1$ & $30 \pm 10$ & $18 \pm 1$ & $18 \pm 1$ \\
N10\% & $371 \pm 8$ & $30 \pm 1$ & $30 \pm 1$ & $13 \pm 1$ & $12 \pm 1$ \\
\hline
\end{tabular}

$2.5 \%$ to $10.0 \%$. With respect to maximum tensile stress, values for composites were not significantly different from that of unfilled $\mathrm{PP}$, while the yield stress shows a tendency of increase. Comparing $\mathrm{P} 15$ and $\mathrm{N} 5 \%$ the yield stress increased from $12 \mathrm{MPa}$ to $31 \mathrm{MPa}$. Comparing P30 and N10\% the increase was from $22 \mathrm{MPa}$ to $30 \mathrm{MPa}$. Strain at maximum stress is not different for PP, P15, and P30. In all composites the values of strain at maximum stress and at break were reduced with the increase of amount of the clay. Strain at break values had a noticeable increase of $712 \%$ for P15, but for P30 this value was reduced to $41 \%$, when compared to that of PP matrix (345\%). This fact could be explained by an excess of compatibilizer that can cause some damage on PP matrix.

These results show that there is no evidence of mechanical properties improvement and the systems can be compared to typical composites of mineral fillers. The pronounced reduction on strain suggests the presence of a fraction of non dispersed clay which acts as typical fillers. This fraction is associated to intercalated structures shown by the X ray diffraction patterns. Even though there should be some intercalation and exfoliation of the organophilic clay, the dispersion was not efficient to get the desired results. Some increase on yield stress can be attributed to the stiffness of the clay layers that contributes to the presence of immobilized polymer phases. This aspect is in agreement to literature ${ }^{[4,7,30]}$.

\section{Conclusion}

$\mathrm{PP}+\mathrm{PP}-\mathrm{g}-\mathrm{AM}$ systems modified with organophilic montmorilonite prepared by melt intercalation showed intercalated structures for a large range of clay concentration. Although the PP crystal phases remain unchanged, crystallization process was influenced by the presence of clay. Nucleating effect was observed during the first step of crystallization followed by a reduction on crystallization rate, probably due to restriction on the polymer chain mobility during the crystal growth. Clay layers promote a reduction on the spherulite size and distortion on spherulite shape. The values of the Avrami index (aprox. 2) remain unchanged for the modified system, with respect to its matrix, and the constant $\mathrm{k}$ presented differences associated to higher amount of clay.

Mechanical properties are very similar to typical composites of mineral fillers. Only the yield stress presented improvement that can be associated to the stiffness of the clay layers that contributes to the presence of immobilized polymer phases.

\section{References}

1. Paul, D. R. \& Robeson, L. M. - Polymer, 34, p.3187 (2008). http:// dx.doi.org/10.1016/j.polymer.2008.04.017

2. Sharma, S. K. \& Nayak, S. K. - Polym. Degrad. Stab., 94, p.132 (2009). http://dx.doi.org/10.1016/j.polymdegradstab.2008.09.004

3. Lai, S-M.; Chen, W-C. \& Zhu, X. S. - Compos. part A, 40, p.754 (2009). http://dx.doi.org/10.1016/j.compositesa.2009.03.006
4. Modesti, M.; Lorenzetti,A.; Bon, D. \& Besco, S. - Polym. Degrad. Stab.,91, p. 672 (2006). http://dx.doi.org/10.1016/j.polymdegradstab.2005.05.018

5. Benetti, E. M.; Causin, V.; Marega, C.; Marigo, A.; Ferrara, G.; Ferraro, A.; Consalvi, M. \& Fantinel, F. - Polymer, 46, p.8275 (2005). http:// dx.doi.org/10.1016/j.polymer.2005.06.056

6. Százdia,L.;Pukánszky Junior,B.;Foldesa,E. \& Pukánszkya,B.-Polymer,46, p.8001 (2005). http://dx.doi.org/10.1016/j.polymer.2005.06.108

7. Zhou, Y.; Rangari, V.; Mahfuz, H.; Jeelani, S. \& Mallick, P. K. - Mater. Sci. Eng., A, 402, p.109 (2005). http://dx.doi.org/10.1016/j.msea.2005.04.014

8. Malucelli, G.; Ronchetti, S.; Lak, N.; Priola, A.; Dintcheva, N. T. \& Mantia, F. P. - Eur. Polym. J., 43, p.328 (2007). http://dx.doi. org/10.1016/j.eurpolymj.2006.11.024

9. Dong, Y. \& Bhattacharyya, D. - Compos. part A, 39, p.1177 (2008). http://dx.doi.org/10.1016/j.compositesa.2008.03.006

10. Hambir, S.; Bulakh, N. \& Jog, J. P. - Polym. Eng.Sci., 42, p.1800 (2002). http://dx.doi.org/10.1002/pen.11072

11. Yao, H.; Zhu, J.; Morgan, A. B. \& Wilkie, C. A. - Polym. Eng.Sci., 42, p.1808 (2002). http://dx.doi.org/10.1002/pen.11073

12. Pavlidou, S. \& Papaspyrides, C. D. - Prog. Polym. Sci., 33, p.1119 (2008). http://dx.doi.org/10.1016/j.progpolymsci.2008.07.008

13. Fanegas, N.; Gómez, M.A.; Marco, C.; Jiménez, I. \& Ellis, G. - Polymer, 48, p.5324 (2007). http://dx.doi.org/10.1016/j.polymer.2007.07.004

14. Lonkar, S. P.; Morlat-Therias, S.; Capera, N.; Leroux, F.; Gardette, J. L. \& Singh, R. P. - Polymer, 50, p.1505 (2009). http://dx.doi. org/10.1016/j.polymer.2009.01.031

15. Xu, J-T.; Wang, Q. \& Fan, Z-Q. - Eur. Polym. J., 41, p.3011 (2005). http://dx.doi.org/10.1016/j.eurpolymj.2005.04.042

16. Lv, Z.; Wang, K.; Qiao, Z. \& Wang, W. - Mater. Des., 31, p.3804 (2010). http://dx.doi.org/10.1016/j.matdes.2010.03.028

17. Shi, J.; Yang, X.; Wang, X. \& Lu, L. - Polym. Test., 29, p.596 (2010). http://dx.doi.org/10.1016/j.polymertesting.2010.03.007

18. Zhang, Z.; Wang, C.; Yang, Z.; Chen, C. \& Mai, K. - Polymer, 49, p.5137 (2008). http://dx.doi.org/10.1016/j.polymer.2008.09.009

19. Zhou, H.; Ying, J.; Xie, X.; Liu, F. \& Li, D. - Polym. Test., 29, p.915 (2010). http://dx.doi.org/10.1016/j.polymertesting.2010.06.004

20. Hao, W.; Yang, W.; Cai, H. \& Huang, Y. - Polym. Test., 29, p.527 (2010). http://dx.doi.org/10.1016/j.polymertesting.2010.03.004

21. Lonka, S. P.; Morlat-Therias, S.; Capera, N.; Leroux, F.; Gardette, J. L. \& Singh, R. P. - Polymer, 50, p.1505 (2009). http://dx.doi. org/10.1016/j.polymer.2009.01.031

22. Lei, S. G.; Hoa, S. V. \& Ton-That, M-T. - Compos. Sci. Technol., 66 p.1274 (2006). http://dx.doi.org/10.1016/j.compscitech.2005.09.012

23. Maiti, P.; Nam, P. H.; Okamoto, M.; Kotaka, T.; Hasegawa, N. \& Usuki, A. Polym. Eng.Sci., 42.9, p.1864 (2002). http://dx.doi.org/10.1002/pen.11079

24. Yuan, Q.; Awate, S. \& Misra, R. D. K. - Eur. Polym. J., 42, p.1994 (2006). http://dx.doi.org/10.1016/j.eurpolymj.2006.03.012

25. Paiva, L. B.; Morales, A. R. \& Guimarães, T. R. - Mater. Sci. Eng., A, 447, p.261 (2007). http://dx.doi.org/10.1016/j.msea.2006.10.066

26. Vladimirov, V.; Betchev, C.; Vassiliou, A.; Papageorgiou, G. \& Bikiaris, D. - Compos. Sci. Technol., 66, p.2935 (2006). http://dx.doi. org/10.1016/j.compscitech.2006.02.010

27. Cho, K. W.; Li, F. K. \& Choi, J. - Polymer, 40, p.1719 (1999). http:// dx.doi.org/10.1016/S0032-3861(98)00404-2

28. Perrin-Sarazin,F.; Ton-That, M-T.; Bureau,M.N.\& Denaul, J. - Polymer,46, p.11624 (2005). http://dx.doi.org/10.1016/j.polymer.2005.09.076

29. Avella, M.; Cosco, S.; Di Lorenzo, M. L.; Di Pace, E.; Errico, M. E. \& Gentile, G. - Eur. Polym. J., 42, p.1548 (2006). http://dx.doi. org/10.1016/j.eurpolymj.2006.01.009

30. Liu, X. \& Wu, Q. - Polymer, 42, p.10013 (2001). http://dx.doi. org/10.1016/S0032-3861(01)00561-4

Enviado: 04/11/10

Reenviado: 10/03/11

Aceito: $29 / 04 / 11$ 